\title{
Outbreak of brucellosis in buffaloes aborted in village Mahuan, district Mainpuri, U.P., I ndia- A case report
}

\author{
Udit Jain ${ }^{1}$, Basanti Bist ${ }^{1}$, Sahzad $^{2}$, Pragati $^{1}$, Kuldeep Dwivedi $^{3}$ \\ Pandit Deen Dayal Upadhayay Veterinary and Animal Science University (DUVASU), Mathura, U.P., 281001, India \\ 1. Department of Veterinary Public Health, 2. Regional Research Center, FMD project, \\ 3. Department of Gynaecology and Obstetrics \\ Corresponding Author: Udit Jain, email: druditjain@hotmail.com \\ Received: 02-06-2012, Accepted: 26-06-2012, Published online: 30-11-2012
}

\section{How to cite this article:}

Jain U, Bist B, Sahzad, Pragati and Dwivedi K (2013) Outbreak of brucellosis in buffaloes aborted in village Mahuan, district Mainpuri, U.P., India- A case report, Vet World 6(1):51-52. doi: 10.5455/vetworld.2013.51-52

\begin{abstract}
Aim: Outbreak of bovine brucellosis in buffaloes aborted in a village Mahuan of District Mainpuri, Uttar Pradesh is described.

Materials and Methods: A total of 15 serum samples were collected from a aborted buffaloes. All the sera samples were tested by serological tests, Rose Bengal Plate Test (RBPT) and Standard Tube Agglutination Test (STAT).

Results: Clinical history of the condition complimented with detailed examination of the affected animals revealed that $50 \%$ (15/30) buffaloes were aborted between 6-9.5 months of pregnancy. The main clinical signs presented were fever, discharge from vagina and retention of placenta. There was no response of treatment on buffaloes. The antibodies against $B$. abortus were detected in $7(46.6 \%)$ sera samples by RBPT and in $5(33.3 \%)$ by STAT.

Conclusion: The buffaloes involved and the severity of abortions, that necessitated veterinary intervention, it would be necessary to asses the prevalence and economic importance of the disease in rural herds of Uttar Pradesh.
\end{abstract}

Key words: brucellosis, buffaloes, Mainpuri district, outbreak, RBPT, STAT

\section{I ntroduction}

Brucellosis is a transmissible disease of socioeconomic and public health importance that may act as a barrier to trade of animals and animal products [1]. The disease induces infertility, delayed heat, interrupted lactation, loss of calves, wool and milk production. In India, the occurrence of brucellosis is to the extent of $10 \%$ in marginal herd and $50 \%$ in organized farms and the economic impact of this disease was estimated to run over Rs. 500 crores annually [2]. About 500,000 cases of human brucellosis are estimated to occur worldwide every year [3].

\section{Case History}

The present case study was performed when the Chief Veterinary Officer, Manipuri informed to Dean, College of Veterinary Science, Mathura by fax about storms of abortions in buffaloes (approx. 20) of village Mahuan since last one months and also requested to send team for diagnosing the cause of abortions. The present investigation was aimed to collect history of abortions and diagnose the cause of abortion storm by serological tests and to declare it outbreak.

An investigation team visited a village Mahuan on dated 14-09-2011 and collected history from the farmers whose buffaloes have been aborted previously and some were still showing symptoms of abortions with in 12-24 hrs. Symptoms of abortions were discharge from vagina, fever and in some animals decrease in milk production etc. Following abortion all the buffaloes suffered from retained foetal membrane which has removed by the local veterinarian. Three buffaloes were suffering from fever. Buffaloes did not respond to routine treatment. Attempt were made to treat buffaloes suspected for brucellosis immediately by following drugs viz. Inj Duraprogen $750 \mathrm{mg}$, 3ml ( $250 \mathrm{mg} / \mathrm{ml}, 17$ alpha hydroxyl progesterone caproate, Vet care Ltd.) by intramuscular route at a interval of one month of gap. Antibiotics like Dicrysticine (Streptomycin 2.5g, Procaine penicillin 15 lac IU, penicillin G sodium 1 lac IU, Zydus)/ Enrocin $15 \mathrm{ml}$ (100mg/ml, Pfizer) / Oxy vet LA $30 \mathrm{ml}(1 \mathrm{ml} / 10 \mathrm{Kg}$ body weight, oxytetracycline dihydrate, Pfizer co. ltd.) were given intramuscularly/ intravenously for 3-5 days to get rid of infection of genital tract. Inj Melonex $20 \mathrm{ml}$ (INTAS pharmaceutical Ltd.) and Inj Anistamine 10ml (Pheniramine maleate $22.75 \mathrm{mg} / \mathrm{ml}$, INTAS pharmaceutical Ltd.) were also given for 2 consecutive days.

\section{Materials and Methods}

A total of 15 blood (sera) samples were collected from aborted buffaloes as per the guidelines of Institutional Animals Ethics Committee (IAEC) (Table1). These samples were tested for brucellosis by Rose Bengal Plate Test (RBPT) and Standard Tube Agglutination Test (STAT) [4,5].

\section{Results and Discussion}

The antibodies against B.abortus were detected in $7(46.6 \%)$ sera samples by RBPT and in $5(33.3 \%)$ by STAT. The positive samples showed antibody titre of 1:80 to 1:320 I.U. Five sera samples were found suspected for brucellosis by STAT and remaining five were found negative both in RBPT and STAT (Table-1). 
Table-1. Results of sera samples showing positivity by RBPT and STAT

\begin{tabular}{lccc}
\hline SI. No. & Animal No. & RBPT & STAT (Titre in I.U.) \\
\hline 1 & B-1 & - & S $(1: 20)$ \\
2 & B-2 & ++ & $+(1: 160)$ \\
3 & B-3 & - & - \\
4 & B-4 & +++ & $+(1: 320)$ \\
5 & B-5 & + & $+(1: 80)$ \\
6 & B-6 & + & $+(1: 80)$ \\
7 & B-7 & - & - \\
8 & B-8 & - & $\mathrm{S}(1: 20)$ \\
9 & B-9 & - & - \\
10 & B-10 & ++ & $+(1: 160)$ \\
11 & B-11 & - & $\mathrm{S}(1: 20)$ \\
12 & B-12 & + & $\mathrm{S}(1: 20)$ \\
13 & B-13 & - & - \\
14 & B-14 & + & - \\
15 & B-15 & - & \\
\hline
\end{tabular}

Note- - = negative samples showing $\leq 10$ IU titre in STAT, S- Suspected

No response was observed in buffaloes suspected for brucellosis even after treatment because of the presence of Brucella abortus infection in buffaloes of that village. Efficacy and seroprevalence of brucellosis were also in agreement with the findings of several workers [6-9]. They reported high percentage (55\%) of seropositivity. Sero positivity by RBPT and STAT was observed lower i.e. $9.3 \%$ and $7.8 \%$ [10]. In conclusion, the higher seropositivity could be due to the presence of favourable conditions viz. high humidity and temperature for the propagation of causal agent and also the lack of calfhood vaccination.

This study emphasizes on the immediate measures to control the disease in healthy animals by segregation of positive animals because treatment is not recommended in brucellosis positive animals.

\section{Acknowledgements}

The authors are thankful to Hon'ble Vice Chancellor, Veterinary University (DUVASU), Mathura and Dean, Veterinary College, Mathura and for providing necessary facilities to carry out this work. The help rendered by laboratory staff of the department is also acknowledged.

\section{References}

1. Renukaradhya, G.J., Isloor, S. and Rajasekhar, M. (2002)
Epidemiology, zoonotic aspects, vaccination and control/ eradication of brucellosis in Indian. Vet. Microbiol., 90:183195.

2. Rajasekhar, M. (1995) In: Bovine brucellosis progressive control programme concept paper. Animal disease monitoring and surveillance project. Indian Council of Agricultural Research, Bangalore.

3. Anon.,(1986) Brucellosis eradication uniform methods and rules. USDA, APHIS, VS, 48

4. Alton, G.G., Maw, J., Rogerson, B.A. and McPherson, G.G. (1975a) The serological diagnosis of bovine brucellosis: An evaluation of complement fixation, serum agglutination and Rose Bengal test. Aust. Vet.J., 51:57-63.

5. Alton, G.G., Jones, L.M. and Pietz, D.E. (1975b) Laboratory techniques in brucellosis. Second Ed., Monograph series no. 55, W.H.O., Geneva.

6. Bhattacharya, D.K., K.Ahmed and Rahman, H. (2005) Studies on seroprevalence of bovine brucellosis by different tests. J.Vet.Pub.Hlth., 3(2):131-133.

7. Varasada, R.N., M.N. Brahmabhatt, J.B.Nayak and Bhong, C.D. (2009) Seroprevalence of brucellosis in cattle of central Gujarat. J.Vet.Pub.Hlth., 7(1):67-68.

8. Priyadarshini, A., Sarangi, L.N., Palai, T.K., Ranabijuli, S., Panda, H.K. and Mishra, R. (2012) Diagnostic tests for seroprevalence of brucellosis in cattle. Indian Vet. J. , 89 (5): 86-87.

9. Hafiz, A., Hussain, S.A., Bhattacharya, H.K. and Tufani, N.A. (2009) Serological diagnosis of brucellosis in animals and man and its therapeutic management. J.Vet.Pub.Hlth., 7(1):75-77.

10. Kaushik, P., Quasim, A., Kumar, M., Singh, D.K. and Dayal, S. (2010) Seroprevalence of bovine brucellosis in and around Patna, Bihar. J.Vet.Pub.Hlth., 8(2):135-136. 